\title{
An Evaluation Of Helpdesk With Gamification Using Indeks Kepuasan Masyarakat (IKM)
}

\author{
Achmad Muhtadibillah', Husni Teja Sukmana ${ }^{2}$, Nurul Faizah Rozy ${ }^{3}$ \\ Teknik Informatika, Fakultas Sains dan Teknologi \\ Universitas Islam Negeri Syarif Hidayatullah Jakarta ${ }^{1,2,3}$ \\ JI. Ir. H. Juanda No. 95, Tangerang Selatan - Banten 15412 \\ Indonesia \\ e-mail: muhtadi.achmad14@mhs.uinjkt.ac.id', husniteja@uinjkt.ac.id ${ }^{2}$, \\ nurul.faizah@uinjkt.ac.id ${ }^{3}$
}

To cite this document:

Muhtadibillah, A., Sukmana, H., \& Rozy, N. (2019). An Evaluation Of Helpdesk With

Gamification Using Indeks Kepuasan Masyarakat (IKM). IAIC Transactions on Sustainable

Digital Innovation (ITSDI), 1(1), 8-17. Retrieved from https://aptikom-

journal.id/index.php/itsdi/article/view/8

\begin{abstract}
Gamification is a concept of game element that is applied to non-game contexts, Helpdesk is an IT (Information Technology) section. It is first contacted by a user when someone has questions or problems related to IT services. UIN Syarif Hidayatullah Jakarta as a tertiary institution also has a help desk facilities as the tools to solve problems related to IT service. Based on study, the problem that common occurs is, the user is aware of the helpdesk service facilities on campus, but they prefer to make complaints directly to the relevant division. The concept of gamification with elements of points, badges, levels, leaderboard, and rewards is applied to the helpdesk system through the RAD (Rapid Application Development) development method. The method of evaluating the helpdesk system is done in two stages, first pre-test and second post-test. It through two application which is game based helpdesk and non-game based help desk applications. Using Indeks Kepuasan Masyarakat (IKM) as the calculation method of gamification helpdesk and End User Computing Satisfaction (EUCS) as an indicator service of the IKM that will be tested.
\end{abstract}

Keywords: Helpdesk, Gamification, IKM, EUCS, RAD

\section{Introduction}

In this information era, helpdesk has a very important role in ensuring the availability and quality of information technology (IT) services in an organization. Helpdesk is the first IT department that the user contacts when they have questions or problems related to IT services. Helpdesk also an organization that helps handle the needs of customers or users related to questions, services, technical support, or complaints about certain products and services by utilizing a numbering system (request ticket) to facilitate tracking of resolution actions coordinated by a team.

UIN Syarif Hidayatullah Jakarta is one of the colleges that has helpdesk service system. The author made direct observations of the helpdesk at UIN Syarif Hidayatullah Jakarta to find out student knowledge related to helpdesk services within the university. The author takes data

on the use of helpdesk during high sessions June-August and distributes questionnaires to Students of UIN Syarif Hidayatullah Jakarta who already know the helpdesk service system. 


\section{IAIC Transactions on Sustainable Digital Innovation (ITSDI)}

Vol. 1 No. 1 October 2019

Based on the data obtained, at the high session there were 62 incident ticket records originating from students. It is the population during high sessions. Then by using the Slovin formula's method, it can be sampled as 38 users from a total of 62 user population. Furthermore, the authors distributed questionnaires from a total of 38 student respondents, there were $64 \%$ of students knowing how to use helpdesk while $36 \%$ of respondents did not know how to use the helpdesk. There are 36 out of a total of 38 respondents, when there are problems and complaints related to IT service activities in college, they more often make complaints directly to the technicians or related divisions. This happens because user is not satisfied with the helpdesk service that already exists today because the procedure is too complicated and the features of the helpdesk service are inadequate so the respondent is not interested in using it. It is evident from the data obtained and the questionnaire that the author has spread, that student knowledge about helpdesk services is already quite high, but their interest and use is still low. One solution to increase interest and use of help desk is to apply gamification.

\section{Research Method}

Gamification is the concept of applying game elements to non-game elements. The purpose of gamification is to create interaction with users through a mechanism that resembles a game. Users will experience an experience similar to the experience that arises when a user plays a game, which is a pleasant interaction. When playing a game, players are required to reach a certain level, through various obstacles to end a level, and get a reward when successfully ending a level. The elements and characteristics of the game are generally applied to gamification through badges, points, and leaderboard. (Hunter, R. (2011), The Gamification Handbook Everything You Need ToKnow About Gamification, Tebbo).

Based on the results of research conducted by (Farozi, Suyanto, \& Lutfi, 2015), there are several factors that decrease the performance of human resources in a company, one of which is the boredom factor at work. With the establishment of the system using the method of gamification, business applications in the company become more fun to use. One approach taken is to reward users both virtual and nonvirtual when doing activities in the system and other users can see the performance of each user. This has an impact on increasing user engagement and feedback with the application. This engagement is expected to provide positive things in the form of improved performance from users. Based on the explanation of the problem and background above, the researcher designed a help desk information system, using the concept of gamification as a method to increase the interest and activeness of users in reporting problems with IT services within the university.

\subsection{Helpdesk}

(Wooten, 2001), "Help Desk is a formal organization that provides support functions to users of the companies products, services, or technology".

Helpdesk can also act as a single point of contact when users need technical assistance and can be a communication facility between users and support teams in a company (Beisse, 2013).

\subsection{Gamification}

According to (Zichermann, G. \& Cunningham, 2011) Gamification is the process of thinking of games (game thinking) and game mechanics to engage users and solve problems. A similar but more general definition is obtained from (Deterding, Dixon, Khaled, \& Nacke, 2011) Gamification is the use of design elements that make up a game in a non-game context.The term of gamification only began to be heard at the end of 2010, when foursquare boomed with badges (virtual items) obtained when checking in at one or several locations. But in reality by definition, this has long been applied in the real world, for example:

1. When a child has difficulty eating, the mother will make the atmosphere more enjoyable by analogizing that food is an airplane that wants to land (in the child's mouth).

2. There is a program to buy 10 get 1 (using a stamp or shopping receipt).

3. The existence of a program at one credit card vendor that provides benefits can order plane tickets one day faster than others. 
4. There are reward points (virtual currency) that can be exchanged for certain items.

5. There is a voting system that uses SMS in several reality programs to keep the person in the event.

\subsection{Design Help Desk Gamification}

\subsubsection{Identification Helpdesk non-game}

At the identification stage, the non-helpdesk design is called the Centerdesk System, designing the helpdesk based on concepts in the ITIL Service Operation. There are various service operation processes at ITIL, including incident management, problem management, access management, request fulfillment, and event management. However, the authors only chose incident management in this study. The author chose this because incident management has always been the main priority problem that occurs in the helpdesk. (Krisdanto Surendro \& Sarifah Putri, 2016).

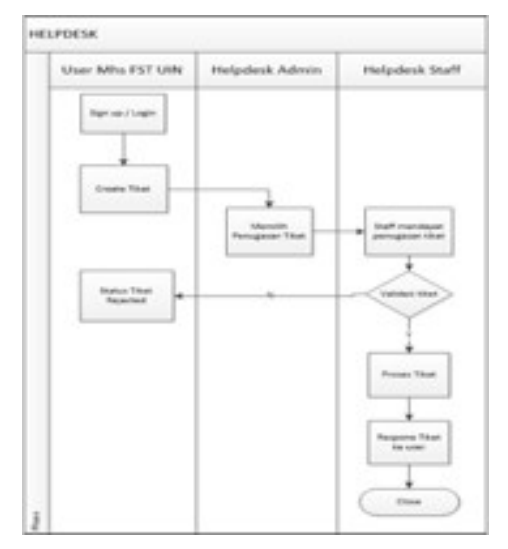

Tabel 2. 1 Table design helpdesk

There are ticket statuses that have 4 conditions:

1. New

New is a switch over condition, which is when the user makes a ticket on the system and waits for confirmation from the staff regarding the status of the next ticket.

2. Open

Open is a condition that the ticket has been received by the staff and will be done immediately in order to achieve the desired solution.

3. Solved

Solved is the condition of the ticket has been completed or closed.

4. Rejected

Rejected is the condition of the ticket being refused by the staff with the conditions and rules that apply to the system.

\subsubsection{Identification Help Desk Gamification}

At the identification stage of the helpdesk with the concept of gamification called the Fundesk System, the authors conducted a literature study of several books and research journals that will be used in this study. Based on research conducted (Krisdanto Surendro \& Sarifah Putri, 2016) the design of gamification is: 


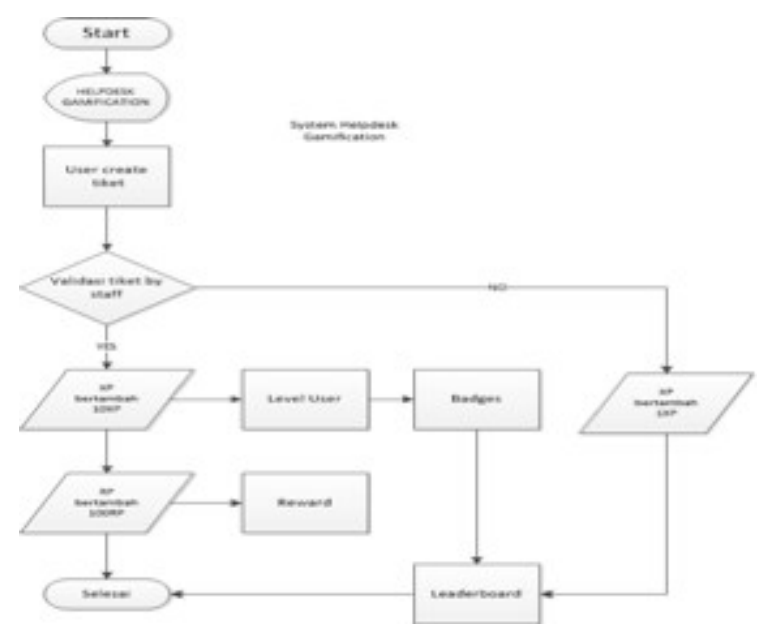

Figure 2. 1 flow fundesk

(Source: Krisdanto Surendro \& Sarifah Putri, 2016)

Based on Figure 2.1 the fundesk system has two point conditions namely RP (Redeemable Point) and XP (Xperience Point) which will be automatically given to users based on ticket validation by staff. When the ticket status is rejected, the user will lose RP points but XP points will still increase by $1 \mathrm{xp}$. This condition occurs because even though the ticket status is rejected by the staff, the user has been active and gained experience using the fund system.

Meanwhile, when the ticket status is received by the staff, the user will get 10xp and 100rp according to table 2.2 point rules that apply to the fundesk system (Krisdanto Surendro \& Sarifah Putri, 2016).

\subsubsection{Identification Element Gamification}

In determining the element of gamification, (Hafsah 2018) conducts a similar literature study to determine the elements to be used. Currently there are many elements of gamification, the author has collected the 5 most commonly used elements, namely:

\section{Points}

Point is the most important thing in a gamified system. All gamified systems must accommodate points in both visible and invisible forms (background). A good gamified system will always record the behavior of players in the form of points.

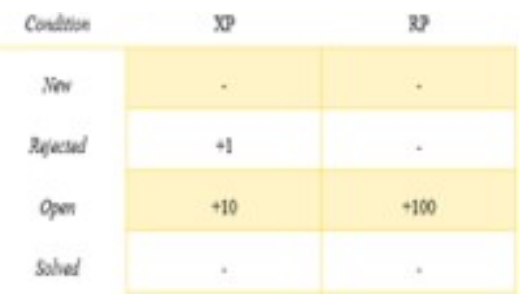

Table 2. 2 Rules of XP dan RP

(Source: Krisdanto Surendro \& Sarifah Putri, 2016) 


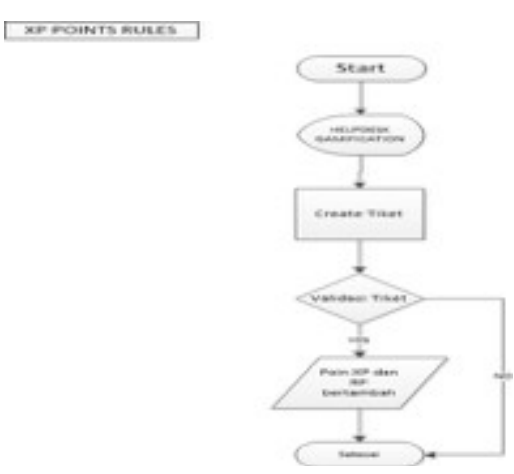

Figure 2.2 Points Rules

\section{Level}

Level is a means to show the development of a player. Levels can be indicated in the form of a progress bar, icon, or metaphor (bronze, silver, gold, and platinum).

\begin{tabular}{|c|c|}
\hline Eevet & Minimum XP \\
\hline 1 & 0 \\
\hline 2 & CXP +10$) 10$ \\
\hline 3 & 20 \\
\hline 4 & 30 \\
\hline 21 & $\ldots \ldots$ \\
\hline
\end{tabular}

Table 2. 1 level

(Source: Krisdanto Surendro \& Sarifah Putri, 2016)

\section{Badges}

Badges can be used for various things, one of which is used to indicate the level of a player. Incorrect and excessive use of badges can cause badges to become worthless. The badges stage is the reputation of the user who uses the helpdesk gamification application. To determine badges is depends on the level that has been reached.

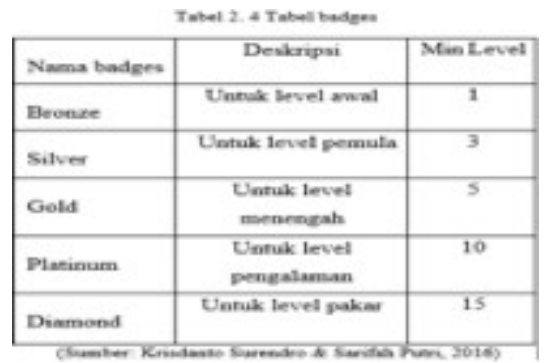

\section{Leaderboard}


IAIC Transactions on Sustainable Digital Innovation (ITSDI)

Vol. 1 No. 1 October 2019

Leaderboard element is a ranking order of users who have the lowest XP to the highest value. The leaderboard element displays the XP point values, levels, and badges of all users in the helpdesk gamification application.

\section{Rewards}

it is an award given as a form of motivation in order to improve an activity. Rewards are earned by exchanging a number of points that have been collected for a specific prize. The use of rewards aims to ensure that users are connected to the system.

\begin{tabular}{|c|c|c|}
\hline Rewards & Deskripsi & Min RP \\
\hline$\div=$ & Free pralea 10.000 & 200 \\
\hline$\div 2$ & Free pulse 20.000 & 500 \\
\hline cosemar & Free Top up Govay & 900 \\
\hline उस्5: & Free Top up Oho & 1500 \\
\hline
\end{tabular}

\subsection{Formula IKM dan EUCS}

In order to score between non-game helpdesk system and game helpdesk system, this research using Indeks Kepuasan Masyarakat (IKM) as the method and End User Computing Satisfication as the indicator service of IKM. Indeks Kepuasan Masyarakat is data and information about the level of community satisfaction obtained by quantitative and qualitative measurement results of public opinion in obtaining services from public service providers by comparing their expectations and needs.

Indeks Kepuasan Masyarakat is calculated using the weighted average value of each service element determined by the author based on 12 indicators of End User Computing Satisfication (EUCS) elements. In calculating of IKM for the 12 service elements studied, each service element has the same weighting with the following formula:

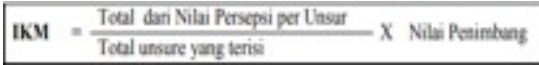

Each option of questionnaire has weight with the following rules :

$$
\begin{array}{ll}
\text { Very dissatisfied }=1 & \text { Satisfied }=3 \\
\text { Dissatisfied }=2 & \text { Very Satisfied }=4
\end{array}
$$

To facilitate the interpretation of the IKM assessment, which is between 25-100, the results of the above assessment are converted to a base value of 25 with the following formula:

IKM Unit Pelayanan X 25

From the result of data processing, the following perception results are obtained to: 
IAIC Transactions on Sustainable Digital Innovation (ITSDI)

Vol. 1 No. 1 October 2019

\begin{tabular}{|c|c|c|c|c|}
\hline $\begin{array}{c}\text { NIL.AI } \\
\text { PE.RSE.PSI }\end{array}$ & $\begin{array}{c}\text { NILAI } \\
\text { INTERVAL } \\
\text { IKM }\end{array}$ & $\begin{array}{c}\text { NIL.AI } \\
\text { INTE.RVAL. } \\
\text { KONVERSI IKM }\end{array}$ & $\begin{array}{c}\text { MUTU } \\
\text { PEI.AYANAN }\end{array}$ & $\begin{array}{c}\text { KINER.AA UNIT } \\
\text { PEI.AYANAN }\end{array}$ \\
\hline 1 & $1,00-1,75$ & $25-43,75$ & D & Tidak baik \\
\hline 2 & $1,76-2,50$ & $43,76-62,50$ & C & Kurang baik \\
\hline 3 & $2,51-3,25$ & $62,51-81,25$ & B & Baik \\
\hline 4 & $3,26-4,00$ & $81,26-100,00$ & A & Sangat baik \\
\hline
\end{tabular}

Table 2.6 Legend score of IKM

\begin{tabular}{|c|c|c|}
\hline Item & Question & Dimension \\
\hline EUCS 1 & $\begin{array}{l}\text { Does the site provide the practice information } \\
\text { you need? }\end{array}$ & Content \\
\hline EUCS 2 & $\begin{array}{l}\text { Does the site information content meet your } \\
\text { need? }\end{array}$ & Content \\
\hline EUCS 3 & $\begin{array}{l}\text { Did the site provide help that seemed to be just } \\
\text { about exactly what you need? }\end{array}$ & Content \\
\hline EUCS 4 & Did the site provide sufficient information? & Content \\
\hline EUCS 5 & Was the site accurate? & Accuracy \\
\hline EUCS 6 & Were you satisfied with the accuracy of the site? & Accuracy \\
\hline EUCS 7 & $\begin{array}{l}\text { Did you think the site information is presented in } \\
\text { a useful format? }\end{array}$ & Format \\
\hline EUCS 8 & Was the site information is clear? & Format \\
\hline EUCS 9 & Was the site friendly? & Ease of use \\
\hline EUCS 10 & Was the site easy to use? & Ease of use \\
\hline EUCS 11 & Did you get the information you need quickly? & Timeliness \\
\hline EUCS 12 & Did the site provide up to date information? & Timeliness \\
\hline
\end{tabular}

Table 2. 7 item EUCS

source :(Abdinnour-Helm, Chaparro, \& Farmer, 2005) 


\section{IAIC Transactions on Sustainable Digital Innovation (ITSDI)}

Vol. 1 No. 1 October 2019

EUCS model was developed by Doll and Torkzadeh (1988) which is used to measure the satisfaction of end-users of the computer. They developed a measuring instrument of satisfaction that is an instrument of end-user computing satisfaction (EUCS). Doll and Torkzadeh developed the EUCS instrument consisting of 12 items by comparing the environment consisting of traditional data with the end-user computing environment, which contained 5 components: Content, Accuracy, Form, Format, Ease and Ease Timeliness (timeliness). (Doll, 1998).

\section{Findings}

\subsection{Problem}

Pre-Test is the testing of non-gamebased helpdesk. The result of pre-test System is Good which has a total of score 78.42.

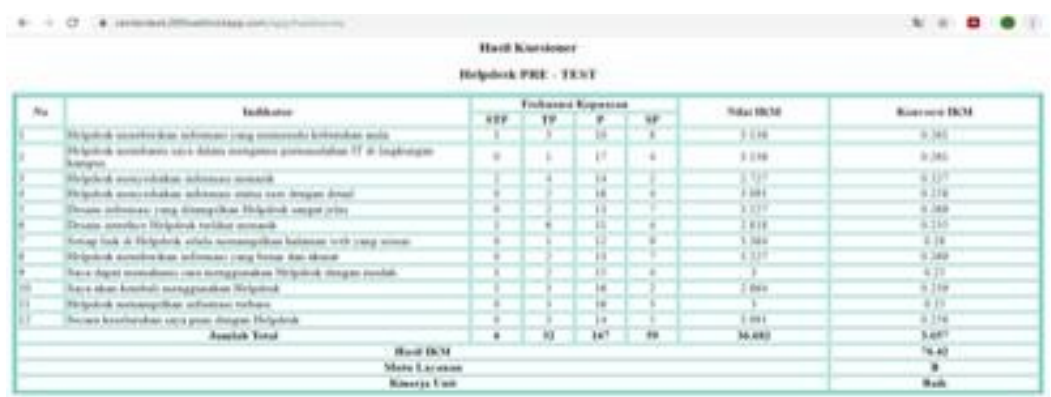

Figure 3.1

\subsection{Research Implementation}

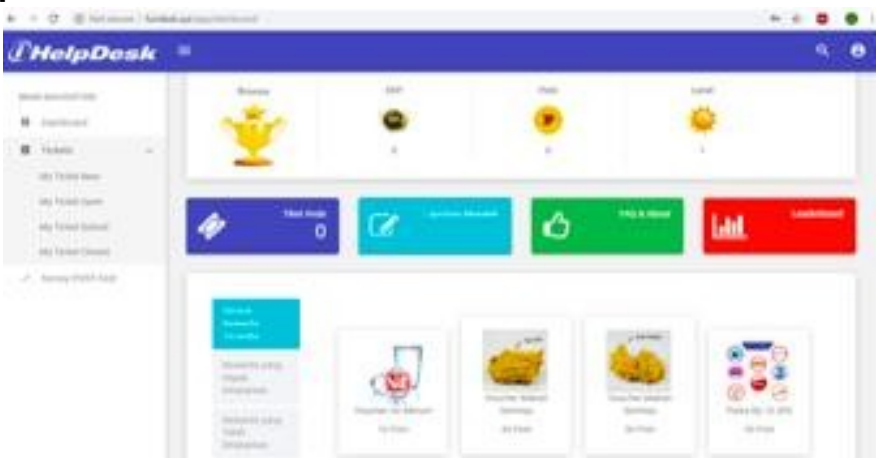

Figure 3.2 Dashboard system

Figure 3.2 is the interface dashboard of Fundesk System. There are some list menu, survey menu, FAQ, Rewards, status gamification, and profile user. Evaluation of helpdesk with gamification is using questionnaire method. By designing game-based helpdesk which is named Fundesk. System Fundesk will be testing by sampled of user where they were. 


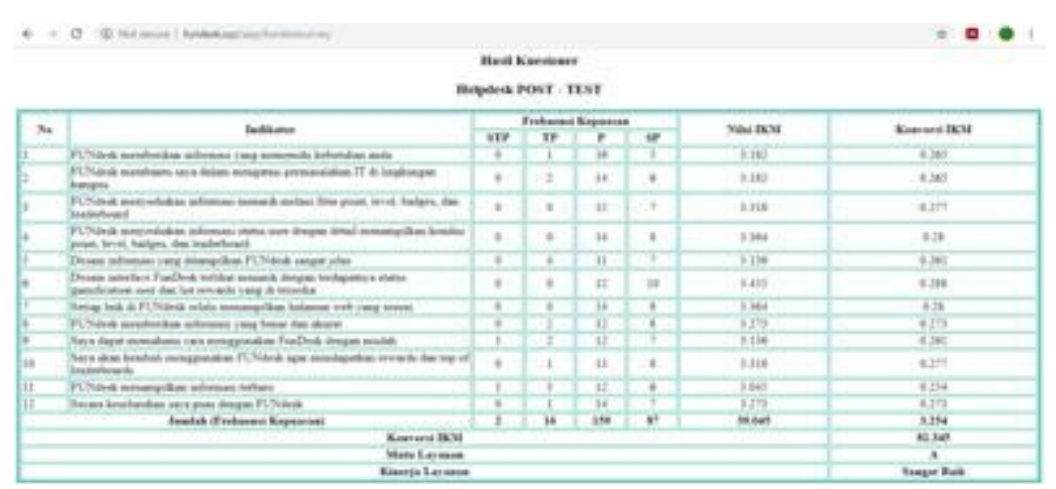

Figure 3.3 Questioner Result

\section{Conclusion}

Based on the results of research that has been done, the author has built a helpdesk system with the concept of gamification. The gamification elements used are points, levels, badges, leaderboard and rewards. Evaluation of the study was carried out using the IKM and EUCS methods as a testing method.

From both of the test, results of Pre-test get the final score of IKM 76.42, or according to table 2.6 (Legend score of IKM) according to the quality of service B (good) results while the Posttest gets the final score of IKM 81.34 or according to the support of service A (very well). Related, the final results of the study showed the helpdesk service system with the concept of gamification (Fundesk System) has proven to have a higher score than the conventional helpdesk service system (Centerdesk System).

\section{References}

[1] Beisse, F. (2009). A Guide to Computer User Support for Help Desk and Support Specialists. 674. Retrieved from http://books.google.com/books?id=4biXfFjMbdEC\&pgis=1

[2] Sangadji, E. M., \& Sopiah. (2010). Metodologi Penelitian Pendekatan Praktis dalam Penelitian. Yogyakarta: ANDI.

[3] Djiwandono, \& Istiarto, P. (2015). Meneliti itu Tidak Sulit: Metodologi Penelitian Sosial dan Pendidikan Bahasa (Deepublish, ed.). Yogyakarta.

[4] OGC. (2007). Service Operation. London: TSO (The Stationery Office).

[5] Murya Yosep. (2014). Towards black box testing of android apps. Proceedings - 10th International Conference on Availability, Reliability and Security, ARES 2015. https://doi.org/10.1109/ARES.2015.70

[6] Deterding, S., Dixon, D., Khaled, R., \& Nacke, L. (2011). From Game Design Elements to Gamefulness: Sebastian Defining "Gamification." In Proceedings of the 15th International Academic MindTrek Conference on Envisioning Future Media Environments - MindTrek '11. https://doi.org/10.1145/2181037.2181040

[7] Rosa, \& Shalahudin, M. (2016). Rekayasa Perangkat Lunak (Terstruktur dan Berorientasi Objek). In Informatika Bandung. https://doi.org/10.1043/15432165(2004)128<897:ICOPEI>2.0.CO;2

[8] Beisse, F. (2013). A Guide to Computer User Support for Help Desk and Support Specialists. 674. https://doi.org/10.1177/0146167207312313

[10] Wooten, B. (2001). Building \& Managing a world class IT help desk. In Library Journal. https://doi.org/10.1519/R-18075.1 
IAIC Transactions on Sustainable Digital Innovation (ITSDI)

Vol. 1 No. 1 October 2019

[11] Zichermann, G. \& Cunningham, C. (2011). Gamification by Design. In Development (Vol. 134).

[12] Conceicao, F., Silva, A., Filho, A., \& Cabral, R. (2014). Toward a gamification model to improve IT service management quality on service desk. Proceedings - 2014 9th International Conference on the Quality of Information and Communications Technology, QUATIC 2014, 255-260. https://doi.org/10.1109/QUATIC.2014.41

[13] Farozi, M., Suyanto, M., \& Lutfi, E. T. (2015). Metode Gamifikasi. 1-10.

[14] Surendro, K., \& Raflesia, S. P. (2016). Designing game-based service desk towards user engagement improvement. Indonesian Journal of Electrical Engineering and Computer Science, 1(2), 381-389. https://doi.org/10.11591/ijeecs.v1.i2.pp381-389

[15] Knapp, D. (2014). A Guide to Service Desk Concepts. Cengage Technology, pp. 1-382. https://doi.org/10.1016/0016-7061(82)90022-2

[16] Zichermann, G. \& Cunningham, C. (2011). (2011). Gamification by Design: Implementing Game Mechanics in Web and Mobile App 